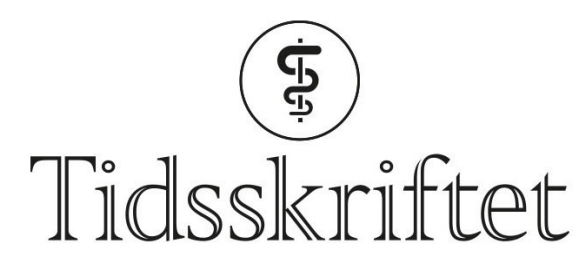

DEN NORSKE LEGEFORENING

\title{
Inkarserert obturatorhernie
}

MEDISINEN I BILDER

STEFFEN WAAGE

E-post: steffenwaage@hotmail.com

Gastrokirurgisk avdeling

Sykehuset i Vestfold

Steffen Waage er overlege i gastrokirurgi.

Forfatteren har fylt ut ICMJE-skjemaet og oppgir ingen interessekonflikter.

På bildet sees et inkarserert obturatorhernie under laparoskopi. Obturatorhernier er sjeldne og representerer mellom 0,07 og $1 \%$ av alle bukhernier $(1,2)$. Som regel er det tynntarmen som hernierer gjennom den 2-3 cm lange og $1 \mathrm{~cm}$ brede obturatorkanalen $\mathrm{i}$ bekkenet. Brokket opptrer oftest hos eldre kvinner, og fordi åpningen på venstre side er beskyttet av sigmoideum, er det vanligst på høyre side. Selv om tilstanden er sjelden, har inkarserert obturatorhernie den høyeste dødeligheten (13-70\% dødelighet i ulike studier) av alle bukveggshernier $(1,2)$. Symptomene er ofte uspesifikke med magesmerter i nedre høyre del av buken, som en sjelden gang kan palperes som en oppfylning medialt på låret. CT er et viktig supplement i utredningen, og funn av tynntarm mellom musculus pectineus og musculus obturatorius er diagnostisk. Behandlingen er kirurgisk, og både åpen og laparoskopisk tilgang er beskrevet. Laparoskopisk kirurgi gir mindre postoperative smerter, færre postoperative komplikasjoner og kortere sykehusopphold (1).

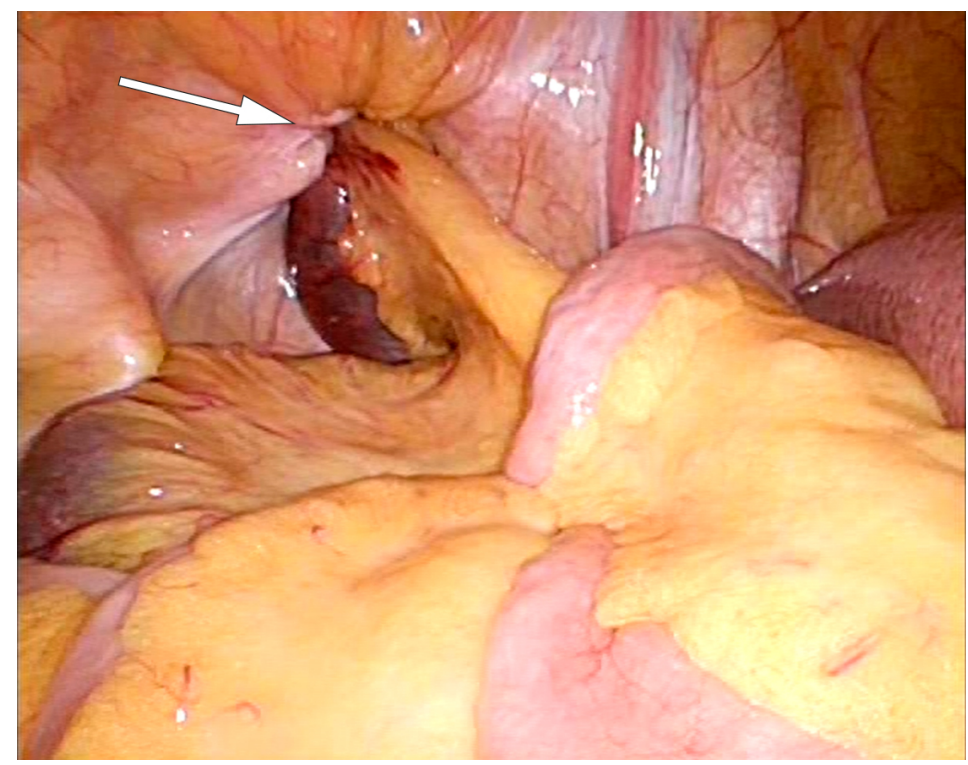

En sprek kvinne i 8o-årene kom inn til sykehus med få timers sykehistorie med akutt innsettende og sterke magesmerter i nedre høyre del av buken. Ved undersøkelse var hun palpasjonsøm i samme område. Hun var tydelig smertepåvirket, men vitale tegn var 
normale. Blodprøver var alle innenfor referanseområdet. CT abdomen viste et høyresidig obturatorhernie med inkarserert tynntarm og begynnende preobstruktiv tarmdilatasjon (se CT-bilde). Pasienten ble først laparoskopert, og det inkarsererte tynntarmssegmentet og brokksekk ble reponert inn i bukhulen. Tarmen var viabel. Funnet var typisk for inkarserert tynntarm i et obturatorhernie. Det ble deretter lagt inn et preperitonealt nett ved hjelp av total ekstraperitoneal plastikk (TEP). Pasienten ble sendt hjem i velbefinnende første postoperative dag.

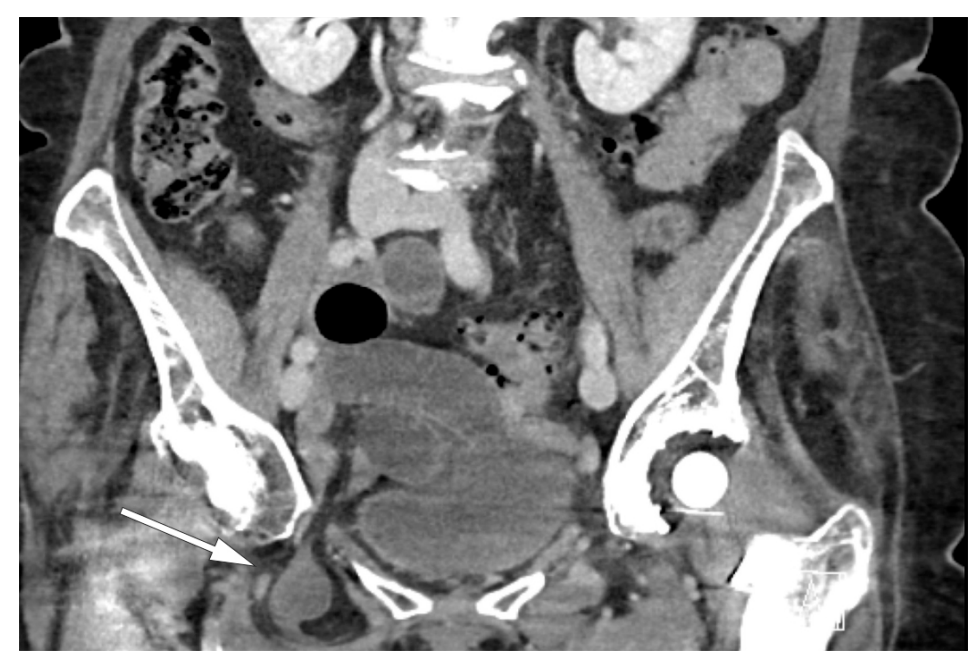

\section{LITTERATUR:}

1. Rito CTC, Travassos J, Patrãcio J et al. Obturator hernia: a rare cause of bowel obstruction. BMJ Case Rep 2017; 2017: bcr-2017-219369. [PubMed]

2. Hodgins N, Cieplucha K, Conneally P et al. Obturator hernia: A case report and review of the literature. Int J Surg Case Rep 2013; 4: 889-92. [PubMed][CrossRef]

Publisert: 13. juni 2019. Tidsskr Nor Legeforen. DOI:10.4045/tidsskr.19.010o Mottatt 31.1.2019, første revisjon innsendt 30.3.2019, godkjent 24.4.2019.

(C) Tidsskrift for Den norske legeforening 2020. Lastet ned fra tidsskriftet.no 